\title{
POUŽITELNOST JONSWAP SPEKTRA PRO VLNOVÉ UDÁLOSTI NA MALÝCH VODNÍCH PLOCHÁCH
}

\author{
THE APPLICABILITY OF JONSWAP SPECTRUM FOR WAVE EVENTS \\ AT SMALL WATER SURFACES
}

Adam Gřegoř ${ }^{*}, 1$

"'gregor.a@fce.vutbr.cz

${ }^{1}$ Vysoké učení technické v Brně, Ústav vodních staveb, Veveří 331/95, 62000 Brno

\begin{abstract}
Abstrakt
Výzkum měl za úkol ověrit, zda je spektrální hustota (tj. vlnové spektrum) větrem vyvolaných vlnových událostí v Hulínské štěrkovně shodná s JONSWAP vlnovým spektrem, které bylo odvozenou pro vlnové události na částečně vyvinutém moři. Data o časovém průběhu úrovně hladiny v nádrži byla zpracována v softwaru MATLAB a vyhodnocena za použití toolboxu WAFO, který vyvinula Lundská univerzita.
\end{abstract}

\section{Klíčová slova}

Vlny, vlnové spektrum, výkonová spektrální hustota, JONSWAP spektrum, WAFO toolbox

\section{Abstract}

Task of the research was to determine whether the spectral density (i.e. spectrum) of wind wave events at Hulínská šterkovna reservoir is the same as the JONSWAP spectrum, which was based at the wave events at partially developed sea. Data about the time course of the water surface elevation at reservoir were processed with use of the MATLAB and WAFO toolbox that was developed by the Lund University.

Key words

Waves, wave spectrum, Power Spectral Density, JONSWAP spectrum, WAFO toolbox

\section{1 ÚVOD}

Pro simulaci vlnových událostí vyvolaných větrem na vodních dílech je nutná správná volba matematického modelu. V současnosti používané matematické modely vycházejí z vlnových spekter, která byla odvozena z měření na mořích nebo oceánech, tedy na vodních plochách mnohonásobně větších, než jsou plochy rybníků a jiných malých vodních nádrží typických pro vnitrozemí většiny států. $Z$ tohoto důvodu se jevilo vhodné ověření platnosti výše zmíněných vlnových spekter pro malé vodní plochy.

Měřní byla prováděna na zaplavené Hulínské štěrkovně, na které se tvoří pouze větrové oscilační vlny. Sběr dat o úrovni hladiny v nádrži probíhal přibližně $3 \times$ za sekundu v letech 2020 a 2021 . Data byla měřena pomocí 3 ultrazvukových čidel, jež byla připevněna na plošině pevně spojené se dnem nádrže. Přesné umístění čidel v rámci souřadnic X, Y, Z bylo ověreno geodeticky [1].

Vyhodnocení nasbíraných dat bylo provedeno v softwaru MATLAB. Z dat byly určeny vlnové události.

Pomocí WAFO toolboxu byly pro každou vlnovou událost vygenerovány výsledky ve formě vlnových spekter. Výsledky bylo možno rozdělit do 2 skupin. První skupina obsahovala výkonová vlnová spektra (anglicky Power Spectral Density, zkr. PSD). Druhá skupina výsledků obsahovala spektra JONSWAP.

Na základě porovnání tvarů vlnových spekter z obou skupin výsledků byl vyvozen závěr.

\section{POPIS SOUČASNÉHO STAVU}

Při zkoumání oceánů se uvažuje s tzv. stavem moře, což tvar mořské hladiny v daném časovém okamžiku [2]. Stav moře, při kterém již nedochází k nárustu výšky vln, se označuje jako tzv. plně vyvinuté moře [3]. Mezi spektra odvozená pro moře patří např́klad spektra Pierson-Moskowitz, Ochi-Hubble, Torsethaugen, a JONSWAP [4], [5]. 
Spektrum Pierson-Moskowitz bylo vyvozeno z dat naměřených v Severním Atlantském oceánu pro plně vyvinuté moře a uvažuje s předpokladem, že se v moři nevyskytují vlny, které se mohou samy šírit dál bez toho, aby jim v tom pomáhal vítr [3], [4]. Spektrum je závislé jen na 1 vstupním parametru [4]. Vzhledem k tomu, že spektrum Pierson-Moskowitz neumí pracovat s vlnami, které se samy šíří bez pomoci větru, byla vyvinuta dvouvrcholová spektra, ve kterých první vrchol reprezentuje frekvence vln, které se šíři pomocí větru, a druhý vrchol reprezentuje frekvence vln, které se šírí bez pomoci větru.

Prvním z těchto dvouvrcholových spekter je šestiparametrové vlnové spektrum. Ve skutečnosti závislé pouze na 3 vstupních parametrech (ovšem vznikne spojením 2 tř́parametrových spekter dohromady, tudíž se dá tvrdit, že je závislé na 6 vstupních parametrech). V anglické literatuře bývá uváděno, podle jmen jeho 2 autorů, jako spektrum Ochi-Hubble, nebo jednoduše jako dvouvrcholové spektrum [6]. Spektrum je platné i pro vyvíjející se moře, tj. pro moře, ve kterém ještě dochází k nárustu výšky vln [3], [7], [8]. Hodnoty vstupních parametrů spektra Ochi-Hubble byly zjištěny z 800 sad dat naměřených v Severním Atlantském oceánu [7].

Spektrum Torsethaugen je taktéž dvouvrcholové spektrum, odvozované bylo z měření provedených v Norském moři a Severním moři [8].

Dalším využívaným spektrem je JONSWAP spektrum. Vychází z měření v Severním moři a uvažuje s omezenou délkou oblasti, ve které vítr působí na vodní hladinu [9], [4].

\section{METODIKA}

Výsledky vycházejí z hodnot naměřených úrovní hladin v zatopené Hulínské štěrkovně. Hulínská štěrkovna se nachází ve Zlínském kraji, v okrese Kroměříž v obci Hulín. Geologicky se jedná o seizmicky stabilní a nepoddolovanou oblast tvořenou fluviálními sedimenty (štěrkopísky, písky, jíly). Nádrž se nachází ve trase podzemní vody, který protéká jihozápadním směrem. Na hladinu nejčastěji působí větry z východu [1].

\section{Volba umístění plošiny s měřícím systémem}

Lokalita Hulínská štěrkovna byla zvolena proto, že se jedná o nádrž s malou vodní plochou, na které se působením větru tvoří oscilační vlny. Navíc se jedná o uzavřenou nádrž [1].

Jelikož se nádrž používala $\mathrm{k}$ těžbě, docházelo v ní v době měření v průměru $32 \times$ denně k pohybu plavidel. Vlny vyvolané plavidly mohly nepříznivě ovlivňovat měření. Tento fakt byl zohledněn při volbě umístění plošiny, na které se nacházel měřící systém. Plošina s měřícím systémem byla umístěna tak, aby byl vliv plavidel na měření co nejvíce utlumen, aby se nejednalo o budoucí těžební ložisko a aby se jednalo o oscilačními vlnami co nejvíce namáhanou lokalitu. K umístění plošiny pomohl i vyhotovený 3D digitální model morfologie dna nádrže, který byl pořizen z plavidla pomocí GSS stanice a echolotu. Výsledné umístění plošiny bylo zvoleno u jihovýchodního břehu nádrže [1].

\section{Měřící systém}

Samotný měřící systém byl osazen na plošině, jež byla pevně spojena se dnem nádrže. Jakákoliv manipulace s měřícím systémem vyžadovala použití plavidla. Měřící systém se skládal z centrální jednotky, jednotky sběru dat, 3 ultrazvukových čidel, která snímala úroveň hladiny v nádrži, anemometru, který měřil a ukládal směr a rychlost větru, komunikačního prvku pro sběr dat z anemometru, USB kamery, jež sloužila pro vizuální kontrolu systému, solárním panelem nabíjené baterie a př́slušenství (převodník napětí, kabeláž apod.). Zmiňovaná ultrazvuková čidla snímají úrovně plováků, které jsou pomocí napnutých lanek zafixovány tak, aby jim nebyl umožněn pohyb v horizontální rovině [1].

Jak bylo uvedeno dříve, každé čidlo zaznamenávalo hodnotu úrovně hladiny v nádrži $3 \times$ za sekundu a vyhodnocovala se data $\mathrm{z}$ let 2020 a 2021.

\section{Zpracování dat}

Prvním krokem k vyhodnocení dat byla identifikace vlnových událostí. Vlnovou událostí se rozuměl souvislý úseků dat, který obsahovat alespoň 1000 vln. Identifikace vlnových událostí byla provedena v softwaru MATLAB, který umožňuje práci s velkým objem dat. 


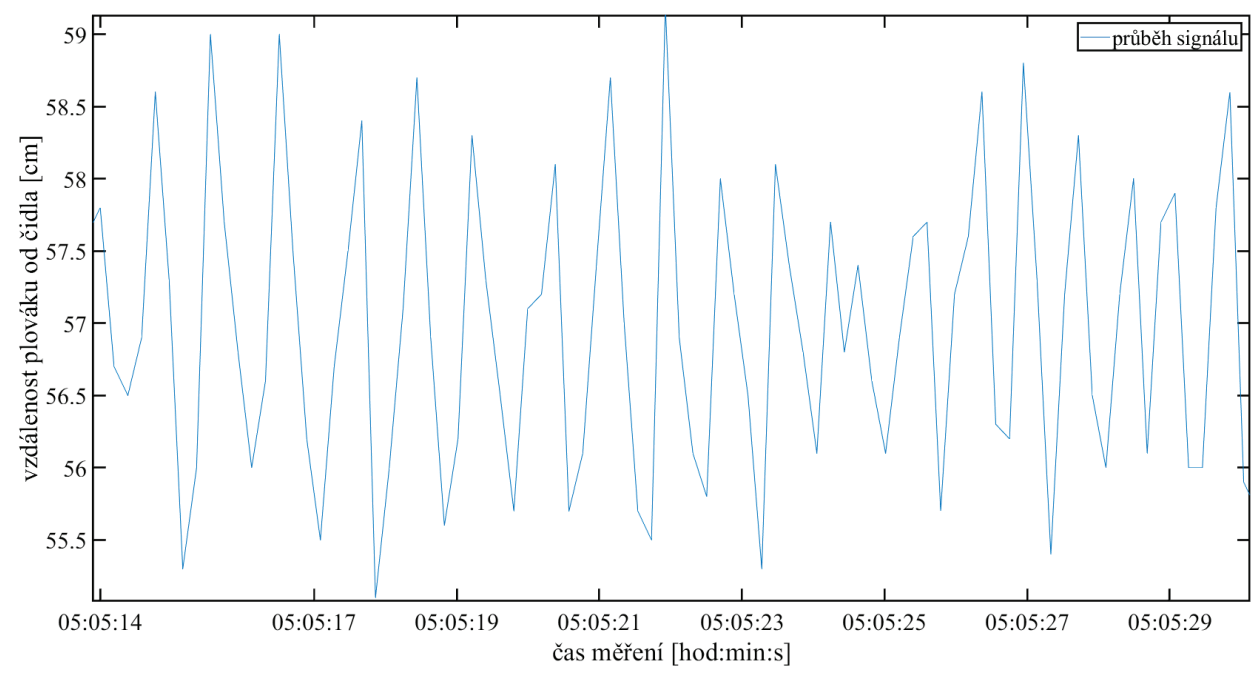

Obr. 1 Výsek naměřených dat z vlnové události z konce roku 2020, čidlo 2.

Tímto způsobem identifikované vlnové události byly dále zpracovány v toolboxu WAFO, jež byl vyvinut Lundskou univerzitou. V kapitole věnující se popisu současného stavu poznání jsou uvedena některá významná vlnová spektra, která byla vyvinuta pro rozsáhlé vodní plochy. Spektrum Pierson-Moskowitz bylo vyvinuto pro plně vyvinuté moře, dvouvrcholová spektra Ochi-Hubble a Torsethaugen jsou vyvinuta pro taková moře, na kterých se vyskytují vlny, které ke svému šíření nepotřebují působení větru [4], [7], [8]. Nepředpokládalo se, že na malé vnitrozemní nádrži v mírných povětrnostních podmínkách, jakou je Hulínská štěrkovna, by došlo k těmto jevům, a proto bylo provedeno porovnání se spektrem JONSWAP, které uvažuje s omezenou délkou oblasti, na které působí vítr [1], [4], [9].

Spektrum JONSWAP je dáno rovnicí [5]:

$$
S^{+}(\omega)=\frac{\alpha g^{2}}{\omega^{M}} \exp \left(-\frac{M}{N}\left(\frac{\omega_{p}}{\omega}\right)^{N}\right) \Upsilon \exp \left(\frac{-\left(\frac{\omega}{\omega_{p}}-1\right)^{2}}{2 \sigma^{2}}\right),
$$

kde $S^{+}(\omega)$ je označení vlnového spektra JONSWAP, $\alpha$ je normalizační parametr, $g$ je tíhové zrychlení [m/ $\mathrm{s}^{2}$ ], $\omega$ je vlnová úhlová rychlost [rad/s], $M$ je konstanta s hodnotou $5[-], N$ je konstanta s hodnotou $4[-], \omega_{\mathrm{p}}$ je vrcholová vlnová úhlová rychlost $[\mathrm{rad} / \mathrm{s}], \Upsilon$ je parametr vrcholovosti, určený rovnicí (4), a $\sigma$ je rozptyl náhodné veličiny, jež nabývá hodnoty 0,07 pokud $\omega$ je menší než $\omega_{\mathrm{p}}$ nebo 0,09 , pokud $\omega$ je větší nebo rovna $\omega_{\mathrm{p}}[-]$.

Normalizační parametr $\alpha$ je dán rovnicí (2), parametr vrcholovosti $\Upsilon$ je dán rovnicí (3) [5]:

$$
\begin{gathered}
\alpha \approx 5,061 \frac{H_{m 0}^{2}}{T_{p}^{4}}(1-0,287 \ln \Upsilon), \\
\Upsilon=\exp \left(3,484\left(1-0,1975\left(0,036-0,0056 \frac{T_{p}}{\sqrt{H_{m 0}}}\right) \frac{T_{p}^{4}}{H_{m 0}^{2}}\right)\right),
\end{gathered}
$$

kde $H_{\mathrm{m} 0}$ je charakteristická výška vlny [m] a $T_{\mathrm{p}}$ je vrcholová perioda [s] [5]. 


\section{VÝSLEDKY}

Identifikováno bylo 30 vlnových událostí. Vygenerovanými výsledky byly 2 křivky, a to křivka výkonové spektrální hustoty (PSD), ozn. $S(\omega)$, a křivka spektra JONSWAP, ozn. $S^{+}(\omega)$, viz Obr. 2, Obr. 3 a Obr. 4.

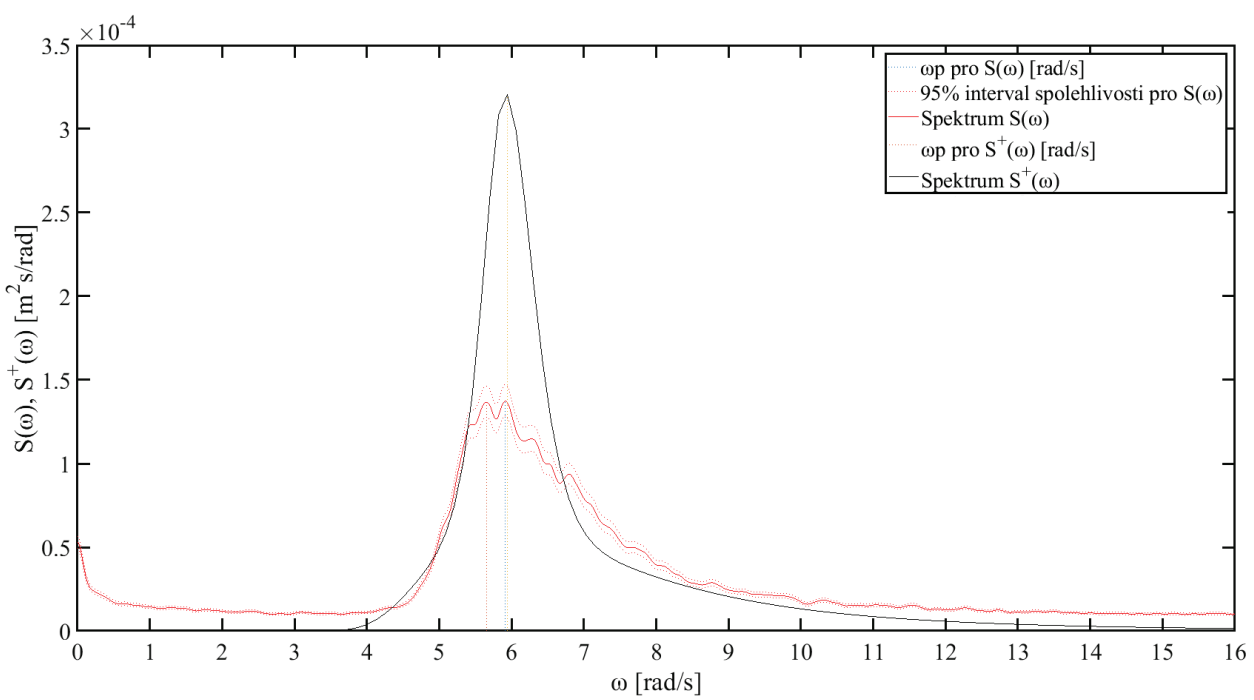

Obr. 2 Porovnání spekter vlnové události z konce roku 2020, čidlo 3.

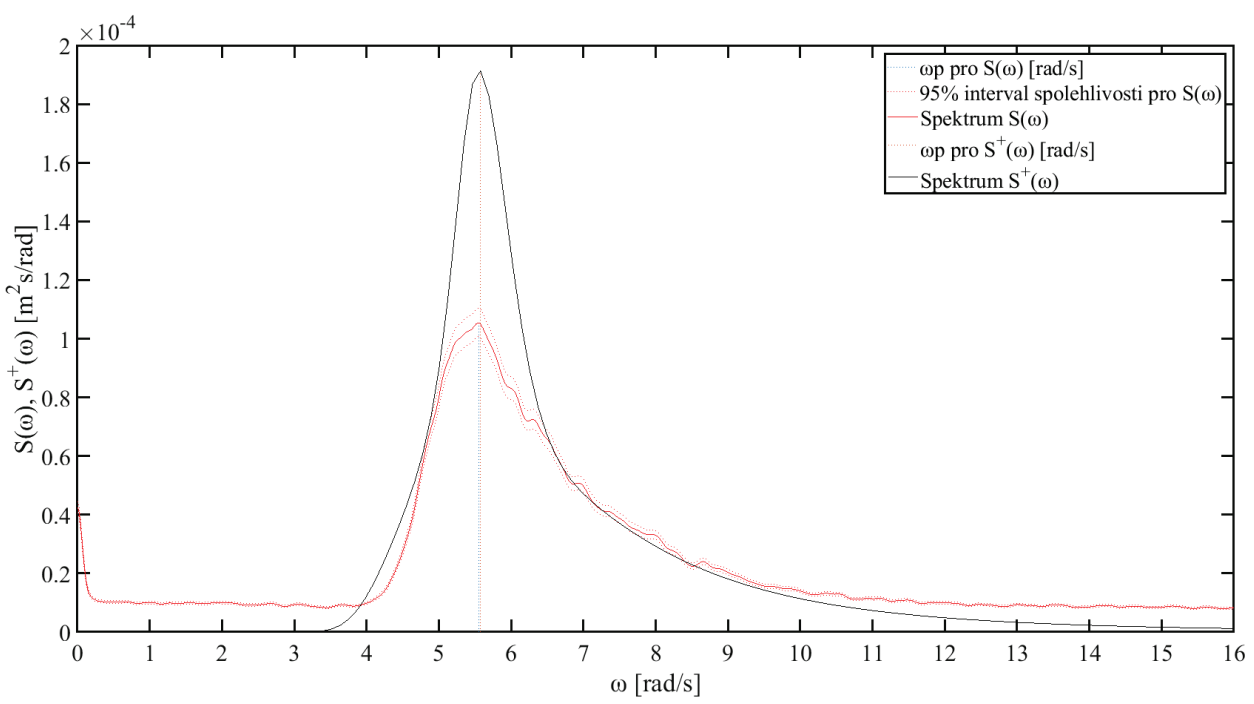

Obr. 3 Porovnání spekter vlnové události z roku 2021, čidlo č. 2. 


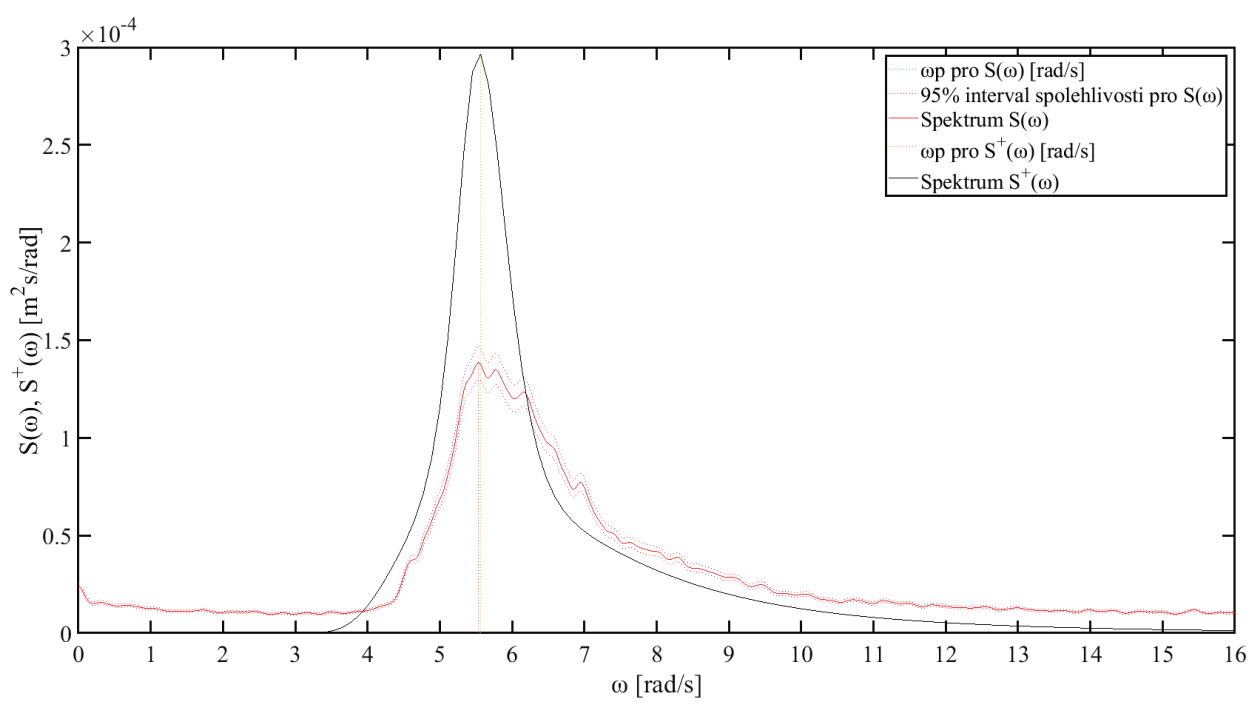

Obr. 4 Porovnání spekter vlnové události z roku 2020, čidlo č. 3.

\section{DISKUZE}

V kapitole s výsledky lze vidět trend, který se opakoval i u dalších vlnových událostí, které v tomto textu nebyly z úsporných důvodů vyobrazeny. Spektrum JONSWAP $S^{+}(\omega)$ při vrcholové frekvenci $\omega_{\mathrm{p}}$ nabývalo přibližně $2 \times$ tolik energie, než jakou nabývala výkonová spektrální hustota $S(\omega)$. Spektrum JONSWAP tím pádem nepopisovalo charakteristiku vlnových událostí s uspokojivou přesností, a tudíž bylo označeno jako nevhodné pro použití na malých vodních plochách.

Ačkoliv bylo vyvinuto značné úsilí k tomu, aby nedošlo k ovlivnění měřené vnějšími vlivy, pro jistotu by bylo vhodné provést měření i na dalších malých vodních plochách (např. na plochách těch vodních děl v České republice, na kterých je veřejnosti vstup zakázán a lodní doprava se na nich neprovozuje). Taktéž by bylo vhodné vyhodnocovat data z delších souvislých časových úseků (1 rok a více), aby byla provedena měření za všech myslitelných klimatických stavů (v současnosti např́klad chybí data naměřená při letních bouřích).

\section{ZÁV̌̌R}

Předpokládalo se, že spektrum JONSWAP vykáže dobrou shodu s výsledky výkonové spektrální hustoty vlnových událostí na malé vodní ploše. Hypotéza byla vyvrácena, spektrum JONSWAP není pro použití na malých vodních plochách vhodné. Pro simulace vlnových událostí na malých vodních plochách by tedy bylo vhodné použít jiné spektrum. Dalšími kroky výzkumu by mělo být ověření vhodnosti dalších typů spekter, jako např. spektrum Pierson-Moskowitz aj.

\section{Poděkování}

Př́ispěvek byl vytvořen v rámci projektu Ochrana konstrukcí vodních staveb a přirozených břehů před účinky oscilačních větrových vln (evidenční číslo: TH0303182), financovaného Technologickou agenturou České republiky. 


\section{Použité zdroje}

[1] Vysoké učení technické v Brně, FAST, Ústav vodních staveb (VUT). Ochrana konstrukcí vodních staveb a přirozených břehů před účinky oscilačních větrových vln, Dílčí zpráva [formát pdf]. Brno: VUT; 2020 [cit. 2021-11-10]. 56 stran. Č́slo dokumentu.: I/2020

[2] Sea state. Glossary of Meteorology [online]. 2012 [cit. 2021-11-10]. Dostupné z: https://glossary.ametsoc.org/wiki/Sea_state Citace 3

[3] Sea States. Manoa.hawaii.edu/ExploringOurFluidEarth [online]. [cit. 2021-11-10]. Dostupné z: https://manoa.hawaii.edu/exploringourfluidearth/physical/waves/sea-states

[4] Techet, A. H. 13.42 Lecture: Ocean Waves [výukový materiál z internetu]. Cambridge: Massachusetts Institute of Technology, Center for Ocean Engineering; 2005 [cit. 2021-11-10]. Dostupné z: https://ocw.mit.edu/courses/mechanical-engineering/2-22-design-principles-for-ocean-vehicles-13-42spring-2005/readings/lec6 wavespectra.pdf

[5] LUND UNIVERSITY, FACULTTY OF ENGINEERING, CENTRE FOR MATHEMATICAL SCIENCES, MATHEMATICAL STATISTICS. Tutorial for WAFO version 2017. Https://www.maths.lth.se/matstat/wafo/index.html: WAFO. Wave Analysis for Fatigue and Oceanography [online]. 2017 [cit. 2021-11-10]. Dostupné z: www.maths.lth.se/matstat/wafo/Wafo_tutorial_2017.pdfS

[6] Waves: Wave spectra. Orcina Ltd - the home of OrcaFlex [online]. [cit. 2021-11-10]. Dostupné z: https://www.orcina.com/webhelp/OrcaFlex/Content/html/Waves, Wavespectra.htm\#OchiHubble

[7] Ochi MK, Hubble EN. SIX-PARAMETER WAVE SPECTRA. Int. Conf. Coastal. Eng. [Internet]. 1976 [cit. 2021-11-10]; 1(15): 17. Dostupné z: https://journals.tdl.org/icce/index.php/icce/article/view/3066

[8] TORSETHAUGEN, Knut. Two peak wave spectrum model. Proceedings of the International Conference on Offshore Mechanics and Arctic Engineering - OMAE [online]. 1993, 1993, (2), 2-10 [cit. 2021-1110]. Dostupné z: https://www.researchgate.net/publication/280689204_Two_peak_wave_spectrum_model/citations

[9] KLAUS, Hasselmann a Dick J. OLBERS. Measurements of Wind-Wave Growth and Swell Decay During the Joint North Sea Sea Wave Project (JONSWAP) [online]. 1973, 2-95 [cit. 2021-11-10]. Dostupné z: https://www.researchgate.net/publication/256197895_Measurements_of_windwave_growth_and_swell_decay_during_the_Joint_North_Sea_Wave_Project_JONSSWAP 